\title{
Питання психології
}

УДК 93/94(477):388.14

DOI: $10.33099 / 2617-6858-20-58-5-183-192$

Солошенко Н. В. старший науковий співробітник НДЛ кафедри суспільних наук НУОУ ім Івана Черняховського https: orcid. org/0000-0002-6537-1107

\section{ЛІКВІДАЦІЯ НАСЛІДКІВ ЧОРНОБИЛЬСЬКОЇ КАТАСТРОФИ 1986 р. ТА ВНЕСОК УКРАЇНСЬКИХ ВІЙСЬКОВОСЛУЖБОВЦІВ}

У статті аналізуються проблеми, які постали та були розв'язані за участі військових частин колишніх Радянського Союзу й УРСР у перші дні та місячі після Чорнобильської катастрофи 1986 р. значною мірою завдяки створенню особливої організачійної структури управління військами. Висвітлюється героїзм та мужність військовослужбовців проявлені при ліквідації наслідків наймаситабнішої аварії в історії атомної енергетики.

Ключові слова: Чорнобильська АEC; катастрофа; військовослужбовці; хімічні та інженерні війська; відселення.

Вступ. Аварія, яка пероросла у масштабну катастрофу гуманітарного, еклогічного та економічного характеру. Ліквідація наслідків Чорнобильської катастрофи надала українським військовослужбовцям неоціненний досвід, що потребує опрацювання.

Мета роботи полягає у всебічному осмисленні місця та значення Чорнобильської катастрофи у історії України новітньої історичної доби та участі українських військовослужбовців у ліквідації катастрофи.

Теоретичне підгрунтя. Проблемі Чорнобильської катастрофи, різними іiі аспектам присвячена низка публікацій як вітчизняних так i зарубіжних дослідників істориків, психологів, екологів, медиків. До них належать Барановська Н., Нецька Л., Маковська Н., Ралдугіна Т., Комар В., Васюта С., Возняк В., Коваленко А., Троицкий С., Дьяченко А. та інші.

Методи дослідження. У процесі дослідження було використано наступні методи: порівняльно-історичний, описовий, контент-аналізу та синтезу.

Результати і обговорення. 3 кожним роком все далі відходять у минуле події, пов'язані з аварією на Чорнобильській АЕС, найбільшою у світі техногенною та екологічною катастрофою. Ще й досі ми не можемо повністю оцінити або хоча б осмислити довготривалі наслідки вибуху на ЧАЕС. Місцевість, яка постраждала від катастрофи становить 1/12 частку всієї території України. Небезпечний рівень радіоактивного забруднення в Україні спостерігається на площі
50 тис. км², а також у значній частині районів Білорусії та Росії, що прилягають до станції. Від аварії у нашій державі постраждали 3,2 млн чоловік, у тому числі понад 1 млн дітей. 3 території України зникла ціла низка раніше квітучих міст та сіл. Було евакуйовано 76 населених пунктів 3 кількістю мешканців понад 90 тис. До зони безумовного (обов'язкового) відселення потрапили 92, а до зони гарантованого державою добровільного відселення - 835 населених пунктів. Під посиленим і постійним контролем перебувають 1288 населених пунктів [8, с. 5]. Утім, до цієї теми ще неодноразово звертатимуться науковці, політики, громадські діячі, медики. А для численної армії переселенців i, власне самих ліквідаторів Чорнобиль назавжди залишатиметься незагоєною раною.

Кожний рік 26 квітня нагадує всім та віддаляє нас від сумної і трагічної в новітній історії події, яка змінила долі багатьох мільйонів людей. Разом із трагедією такого масштабу світ став свідком героїзму пожежників, військовослужбовців, ліквідаторів та усіх людей, які боролися 3 вражаючими унаочненими та невидимими наслідками аварії. Жителі України, як і багатьох інших близьких і віддалених країн континенту, сьогодні схиляють голови перед пам'яттю про тих, хто жертвував собою під час аварійних i рятувальних операцій у перші дні й місяці після вибуху, а також перед десятками тисяч нині сущих, чиє здоров'я постраждало від тієї катастрофи. 


\section{Питання психології}

Дуже прикрим є той факт, що 3 самого початку Чорнобильської трагедії інформація про те, що трапилося тієї ночі, була неповною і недостовірною. Ще й сьогодні світова громадськість не має всебічного уявлення про всі аспекти катастрофи. Навколо цієї події виникло чимало міфів, фальсифікацій, домислів. У деяких колах, керуючись суб'єктивними інтересами й розрахунками, намагаються применшити значення катастрофи чи навіть піддати іiі забуттю. Втім, Чорнобиль не минув, не поринув у безодню. Він промовисто нагадує про себе численними проблемами в різних сферах суспільства, у долях мільйонів людей, житті кожного $з$ нас.

Практично ніхто не зміг об'єктивно оцінити того, що трапилось. Керівництво виявилось професійно і психологічно не підготовленим до адекватного сприйняття жахливого перебігу подій, до ліквідації наслідків аварії такого масштабу. Проте, як добре відомо тепер, від цього залежала не лише система невідкладних заходів, але й порядок дій людей в екстремальних умовах. Імперативною вимогою бугтя були знання радіаційного стану як в центрі подій, так і в містах та селах, уражених радіактивним забрудненням. Але дозиметрична служба ЧАЕС на першому найвідповідальнішому етапі виявилась малоефективною [1, с. 96]. Усвідомлення цього постає хоч і суворим, але доволі повчальним уроком Чорнобиля.

Збіг обставин - 26 квітня 1986 р. керівний склад Міністерства оборони (МО) знаходився на зборах в Прикарпатському військовому окрузі. Міністр оборони маршал Радянського Союзу С.Л. Соколов близько 12 години на екстреному засіданні оголосив про катастрофу, яка сталася на ЧАЕС, i визначив конкретні завдання основним силам МО, виділеним для ліквідації наслідків катастрофи (ЛНК). Згідно наказу міністра було підготовлено полк i приведено до готовності виходу в район катастрофи. Згодом особовий склад полку 3 дезактивації об'єктів укриття АЕС проводив консервування рудого, тобто ураженого радіацією лісу та інші невідкладні заходи.

Головний тягар по організації діяльності військовослужбовців у райні Чорнобиля ліг на плечі начальника Генерального штабу (ГШ) маршала Радянського Союзу С.Ф. Ахромєєва.
Генеральний штаб, взявши на себе у цей період управління розгортанням i функціонуванням оперативного угрупування МО в Чорнобилі, підтвердив готовність і спроможність стосовно вирішення складних завдань державної ваги. За розпорядженням ГШ 26 квітня транспортна авіація перебазовувала підрозділи мобільного загону Приволзького військового округу. Організовувалася радіаційна, повітряна розвідка, доставлялися необхідні вантажі, направлялися в район катастрофи медичні частини для надання першої допомоги постраждалому населенню. Під керівництвом ГШ розроблялись конкретні плани діяльності оперативної групи. На їх основі в оперативних з'єднаннях і частинах розроблялись плани робіт 3 визначенням конкретних завдань, послідовності їх виконання i детальними розрахунками засобів та сил, які терміново направлялися до Чорнобильського угрупування.

У перші години катастрофи до ліквідації наслідків були залучені тільки відомчі формування Міненерго і Мінсередмаша СРСР, МBC, сили Цивільної оборони (ЦО), які впринципі були підготовлені до цієї роботи. Водночас перші вжиті заходи у порівнянні із зростаючим усвідомленням потреб свідчили, що зробленого недостатньо. Імперативність проведення масштабних робіт вимагала необхідного залучення спеціальних підрозділів Міністерства оборони і Цивільної оборони. Саме тому за рішенням Міністра оборони станом на 27 квітня 1986 p. військовотранспортними літаками були перевезені: оперативна група мобільного загону для ліквідації наслідків радіаційної аварії (272 осіб, 65 одиниць техніки) хімічних військ; окремий механізований полк; батальйон спеціального захисту ЦО; а також медичні частини для надання медичної допомоги населенню. Окрім того, для забезпечення роботи військ i цивільних формувань в район катастрофи 30 квітня прибула тилова база.

Звичайно, що за тогочасної практики, політику щодо організації всіх робіт по ліквідації наслідків катастрофи на Чорнобильській AEC визначало партійне керівництво СРСР, зокрема створена 29 квітня Оперативна група Політбюро ЦК КПРС 3 питань ліквідації наслідків аварії. Протоколи 


\section{Питання психології}

ycix iii 40 засідань вийшли друком у книзі „Чорнобиль. Совершенно секретно” (Москва, видавництво „Другие берега”, 1992. Автор i укладач якої є А.Ярошинська). На першому засіданні Оперативної групи була звернена увага начальника Цивільної оборони СРСР генерала армії А.Т. Алтуніна на відсутність чіткої програми по здійсненню комплексу заходів у зв'язку з катастрофою на ЧАЕС, поставлені завдання щодо термінової розробки $\mathrm{i}$ реалізації заходів по усуненню іiі наслідків. Начальнику Генерального штабу маршалу Радянського Союзу С.Ф. Ахромєєву було доручено забезпечити розгортання бригади хімічних військ у максимально стислі терміни i виділити 10 тис. армійських продовольчих пайків для евакуйованого населення.

Вже станом на 2 травня до ліквідації наслідків катастрофи було залучено 20 частин i окремих підрозділів, задіяно більше 6 тис. військових та 1400 одиниць різної техніки. В районі катастрофи та суміжних територіях були розгорнугі з'єднання i частини, які за своєю організаційною структурою, призначенню й технічному оснащенню не мали аналогів у минулому. 3 метою координації дій різних родів військ ЗС в районі ЧАЕС була створена Оперативна група МO під керівництвом Головнокомандувача військами ПівденноЗахідного напрямку генерала армії I.A. Герасимова. Станом на 9 травня додатково були сформовані і розгорнуті дві бригади і 7 полків хімічного захисту, 17 травня - 2 інженернодорожніх полки для зведення водоохоронних споруд 3 метою запобігання розповсюдження радіоактивних речовин. Для створення Чорнобильського оперативного угрупування військ були задіяні мобільні резерви низки військових округів, а саме: Московського, Північно- Кавказького, Середньоазіатського, Приволзько-Уральського і Сибірського.

Враховуючи зростаючі масштаби дезактиваційних робіт, постановою ЦК КПРС за № 634-188 від 29 травня 1986 р. 3 метою мобілізаційного наповнення необхідних з'єднань і частин було дозволено призвати 3 запасу на спеціальні навчальні збори необхідну кількість військовозобов'язаних терміном до 6 місяців. Дійсно, по мірі розгортання робіт продовжувалося нарощування сил: якщо в середині травня угрупування військ нараховувало вже близько 30 тис. чол., то станом на 25 серпня 1986 p. загальна чисельність військових складала близько 40 тис. осіб, включаючи 32 тис. чол., призваних 3 запасу та 10 тис. одиниць техніки. У доповідній записці штабу Цивільної оборони СРСР про хід ліквідації аварії на ЧАЕС повідомлялось, що на 31 серпня 1986 р. у ЛНК на ЧАЕС бере участь 111 з'єднань і частин загальною чисельністю близько 39245 військових, в їх числі були: 1 мотострілкова дивізія, 2 бригади хімічного захисту, 23 полки (в т.ч. оперативно механізовані Цивільної оборони), 28 батальйонів, 8 рот та 49 окремих підрозділів [7, c. 77]. А за весь період участі Збройних Сил у ліквідації наслідків катастрофи крізь Чорнобиль пройшло понад 600 тисяч військовослужбовців.

Основу сил і заходів складали хімічні та інженерні війська, Цивільна оборона, а також медичні батальйони і частини мотострілкової дивізії. Проведення заходів 3 дезактивації організовував Генеральний штаб Збройних сил. Характер державного рівня та унікальність завдань вимагали особливої організації структури управління військами і силами. Були створені оперативні управління при Генеральному штабі, головному штабі ВПС, управліннях начальників хімічних та інженерних військ, головних та центральних управліннях Міноборони. В районі катастрофи було розгорнуто робочий орган Міністерства оборони - Оперативну групу МО, на чолі 3 керівним складом відомства.

Для розробки наукових рекомендацій тактики дій військ, також методів ведення прикладних та пошукових досліджень було створено науковий центр Міністерства оборони. 3 дванадцяти сформованих на різних рівнях оперативних угрупувань дев'ять груп та один науковий центр функціонували безпосередньо в районі катастрофи.

Система управління військами на оперативному i тактичному рівнях під час вирішення багатомасштабних завдань в усьому районі AEC базувалась на основі централізованого принципу управління 3 елементами локального децентралізованого управління. Створена структура органів управління в цілому забезпечила керівництво виконанням завдань Збройних сил, також раціональне використання виділених для цієї 


\section{Питання психології}

мети сил і засобів. Головні зусилля Оперативної групи Міністерства оборони в Чорнобилі були спрямовані на організацію робіт 3 ЛНК на ЧАЕС. Зокрема, ця діяльність зосереджувалася на:

- керівництві дезактивацією забруднених територій;

- узагальненні та аналізі радіаційного стану, доведенні іï в Генеральний штаб i війська;

- нарощуванні зусиль шляхом залучення додаткового контингенту військ, виходячи із з'ясування завдань, викликаних збільшенням обсягу робіт;

- визначенні засобів розв'язання терміново виникаючих додаткових завдань;

- організації взаємодії військових сил 3 формуваннями інших міністерств та відомств;

- проведенні оперативного й

перспективного планування робіт;

- організації всебічного забезпечення, включаючи забезпечення місцевого населення продовольчими товарами тощо.

3 метою упорядкування системи управління військами, підвищення відповідальності за контроль над територією, яка зазнала радіоактивного забруднення, задіянні військові частини поділялись на три сектори з виділенням так званої особливої зони, включаючи територію AЕC з усіма спорудами, ст. Янов і м. Прип'ять.

Роботи на ЧАЕС, які виконувались Збройними силами, були спрямовані на досягнення головної мети - зменшення впливу наслідків катастрофи на населення, яке знаходилося в районі радіоактивного забруднення. Розвідка організовувалася комплексно $з$ залученням не тільки хімічних військ, а й медичних та інженерних. Медичне обстеження проводилося частинами і закладами медичної служби 3 метою виявлення випадків радіаційного ураження населення, інфекційних захворювань, оцінки стану водопостачання i епідеміологічного стану. 3 цією метою на 4 травня 1986 р. було мобілізовано 2 тис. військових-медиків, сформовано п'ять медичних батальйонів, визначені пункти їх розміщення в районах проживання евакуйованого населення. У ході ліквідації наслідків катастрофи медичне обстеження проводилось у рамках санітарного нагляду 3 радіаційної безпеки населення i особового складу, а також санітарно-гігієнічного контролю за розміщенням військ, харчуванням, водопостачанням і умовами виконання робіт 3 дезактивації території АЕС.

Міністерством оборони та спеціалістами промисловості були прийняті рішучі заходи 3 підготовки кадрів, засвоєнню більш ефективних заходів дезактивації. Це дозволило вийти на системний плановий режим виконання робіт, що уможливило за п’ять місяців після катастрофи провести дезактиваційні роботи на загальній площі більше ніж 26100 тис. га. Усього на Чорнобильській АЕС тільки за перші півтора роки військами було оброблено і здано за актами понад 1600 приміщень, продезактивовано близько 4.2 млн. м території станції, 83.5 тис. м² покрівлі, вивезено більше 418 тис. м $^{3}$ забрудненого грунту, сміття та обладнання. В результаті форсування темпів вдалося принципово змінити радіаційний стан навколо AEC i розпочати дезактивацію в середині приміщення, що дозволило ввести на AEC експлуатаційно-технічний персонал $[7$, с. 176].

Важливим напрямом робіт по забезпеченню радіаційної безпеки стали заходи 3 регламентації опромінення особового складу. Спочатку зовні гама-опромінення обмежувалися значенням, рівним п'яти припустимим річним дозам за умов мирного часу, що складало 25 бер. Потім були встановлені більш диференційовані нормативи, а головне нижчі щодо зовнішнього опромінення - 5 бер для всіх категорій військовослужбовців.

Основні зусилля військово-повітряних сил (ВПС) були зосереджені на вирішенні завдань 3 проведення радіаційної і загальної розвідки, локалізації осередку катастрофи, дезактивації місцевості, забезпечення виконання науководослідних робіт, транспортування особового складу та вантажів. Цілий комплекс заходів спрямовувався на припинення викидів радіоактивних речовин у навколишне середовище зі зруйнованого реактора. Цьому були підпорядковані спеціальні вертольото вильоти до епіцентру катастрофи. Усього за період робіт по ЛНК авіацією виконано більше 28 тис. самольото і вертольото вильотів.

На початковому етапі ліквідації наслідків аварії залучалися регулярні військові 


\section{Питання психології}

підрозділи, в яких були і солдати призовного віку. Але поступово вони були замінені чоловіками, призваними з запасу, старшими за тридцятирічний вік. Час їх участі в роботі у зоні аварії суворо обмежувався відповідно до норм припустимого радіаційного опромінення.

Значною мірою основний тягар робіт у подоланні наслідків Чорнобильської катастрофи ліг на плечі військових. Як свідчать фонди Галузевого державного архіву МО України, вже 28 квітня 1986 р. вийшло розпорядження Генерального штабу Збройних Сил СРСР про створення окремого батальйону спеціального захисту.

Створена оперативна група Генерального штабу, згідно директиви ГШ ЗС СРСР від 30 квітня 1986 р., здійснювала збір та аналізувала данні про наслідки катастрофи на АEC, вела підрахунки радіоактивного опромінення залучених військ, брала участь у розробці вказівок МО СРСР та начальника ГШ. Дана група здійснювала також контроль за виконанням завдань покладених на Міністерство оборони, координувала зусилля головних штабів видів ЗС, управлінь центрального апарату і військових округів, які брали участь у ліквідації наслідків. Цілодобове чергування ОГ було запроваджено з 30 квітня $1986 \mathrm{p}$.

Загалом 329 квітня по 5 червня 1986 р. через військові комісаріати до ліквідації наслідків Чорнобильської катастрофи було залучено понад 14 тис. осіб. У подальшому кількість військових підрозділів, задіяних у зоні ЧАЕС, неухильно зростала. А саме, тільки військовими комісаріатами Полтавської області на початку червня 1986 р. у зону відчуження було відправлено 6626 військовослужбовців запасу та 700 одиниць техніки.

Водночас були й упущення, серйозні недоліки. Так, формально здійснювався контроль за станом здоров'я військовослужбовців, не завжди проводився аналіз, узагальнення. Як засвідчують архівні дані, у липні 1986 р. вийшов наказ командира військової частини 33835 щодо порушення 3 питань обліку особового складу і організації робіт $з$ дезактивації в одному із полків хімічного захисту. Його перевірка показала, що облік особового складу “є запущеним”, а “командир, начальник штабу не могли підтвердити, де i скільки військовослужбовців працює у складі окремої команди, яка чисельність направлена на виконання робіт у зоні з підвищеним рівнем радіації. Лікарем частина не обстежувалася, інструктаж перед початком робіт не проводився. Командування, партійнополітичний апарат, штаб полку не забезпечили заходи зі збереження здоров'я особового складу і дотриманням засобів запобігання радіаційної безпеки" [2, с. 7].

Завдячуючи зусиллям залучених 3 перших годин аварії військових, а пізніше й науковців, стало відомо, що поблизу зруйнованого енергоблоку величина гамма поля досягла 2000 рентген на годину (Р/год). Визначалася в основному опроміненням зруйнованого реактора, в середині якого вона доходила до 50000 Р/год. У наступній фазі аварії, що почалася 3 другої половини травня, завдячуючи процесу природного охолодження палива, викиди з блоку знизилися в мільйон разів i, на думку фахівців, він перестав бути визначальним фактором стану глобального радіонуклідного забруднення навколишнього середовища $[2$, с. 8].

Головне навантаження при ліквідації наслідків було покладене на частини i підрозділи хімічних військ, які за своїм основним призначенням повинні захищати військові контингенти і мирне населення від радіоактивного ураження. Багато роботи випало й на долю частин і підрозділів інженерних військ. Тонку операцію виконували сапери [1, с. 223].

Керівництво військовими здійснювали начальник хімічних військ Міноборони СРСР генерал-полковник В.К. Пікалов, заступник командувача ВПС Київського військового округу генерал-майор Н.А. Антошкін, начальник інженерних військ маршал інженерних військ С.І. Аганов [3, с. 60].

Для дезактивації Чорнобильської атомної електростанції i населених пунктів широко використовувалися вертольоти. Першим 3 військових вертольотчиків до Прип'яті прибув генерал-майор Н.А. Антошкін. Зранку 27 квітня за допомогою переносної радіостанції він допоміг приземлитися на території міста вертольотам заступника командуючого військово-повітряними силами округу полковника Б. Нестєрова і командира полку 


\section{Питання психології}

гвардії полковника А. Серебрякова. Було проведено детальну розвідку з повітря території AЕC та іï прилеглої місцевості. Після цього була розроблена детальна схема заходів гелікоптерів на реактор для викиду вантажу. Керував польотами Б. Нестеров, облаштував свій командний пункт на даху міського готелю.

26 квітня вертольотчики вкинули в жерло четвертого енергоблоку 65 т. вантажу, зробили 45 вертольото-вилетів. На засіданні Урядової комісії було визнано, що цього замало. Спочатку засипка реактора здійснювалась простим способом: вертоліт підлітав до реактора, екіпаж відчиняв двері i, цілячись прямо в точку, викидав вантаж вручну.

30 квітня завдяки використанню ковшівгрейдерів було скинуто в два рази більше вантажу - 151 т. Всього за цей день було зроблено 93 вильоти. Майже за три дні військові авіатори у кілька разів збільшили обсяг робіт. Наприклад, завдяки тому, що на найпотужні 3 вертольотів військовики встановлювали по три великі ємкості, що дозволяло за 5 хв. розсіяти широкою смугою 12 тис. літрів рідини.

За допомогою військових вертольотів осередок аварії блокували тепловідводячими і фільтруючими матеріалами, що дозволило суттєво знизити, а потім і припинити викиди радіоактивних речовин в навколишне середовище. Проводились також чимало спеціальних запобіжних заходів щодо запобігання потраплянню радіоактивних речовин із зруйнованого реактора у грунт під четвертим енергоблоком.

Слід наголосити, що засипка реактора не була єдиним видом діяльності вертольотчиків. Військові льотчики провели важливу роботу 3 фотографування аварійного блоку, яке здійснювалось постійно, починаючи 327 квітня 1986 р. були зроблені фотознімки в різних ракурсах, на яких можливо було помітити важливі деталі зовні пошкодженого енергоблоку. Це надавало можливість приймати рішення подальших дій щодо ліквідації наслідків ЧАЕС [1, с. 224].

Застосовувалась спеціальна військова техніка та пожежні машини за допомогою яких обмивались стіни і дахи приміщень. $\mathrm{He}$ відмовлялись і від самих звичайних засобів збору 3 території радіоактивного бруду. Його зчищали бульдозерами, скреперами i захоронювали. Брудні земельні майданчики покривали бетоном, засипали піском, асфальтували.

Найбільш забрудненими в радіаційному відношенні виявились кровельні покриття третього енергоблоку. На них потрапили частки реакторного палива, уламки конструкцій, радіоактивний пил.

Забезпечення радіаційної безпеки військ та населення, зведення до мінімуму опромінення людей - це було головним завданням, яке покликані були розв'язувати військові підрозділи. I його виконання супроводжувалося великим обсягом безперервно здійснюваних заходів. Комплекс цієї роботи охоплював заходи зонування території за даними радіаційної розвідки, дозиметричний контроль та вибір засобів захисту, медичної профілактики і санітарно-гігієнічної обробки. Ці роботи проводилися згідно наказів Міністра оборони і розроблених на їх основі методичних рекомендацій військам з урахуванням обставин.

Багато роботи випало на долю частин і підрозділів інженерних військ, які взяли активну участь у ліквідації наслідків на ЧАЕС. Для керівництва частинами інженерних військ, створених спеціально для виконання специфічних завдань були задіяні кращі фахівці 3 військ, академій, училищ, військових кафедр ряду інститутів. В цілому угрупування інженерних військ складалося із 26 інженерних батальйонів кількістю більше 8000 чоловік і близько 900 одиниць спеціальної техніки.

Технічне керівництво виконанням інженерних завдань було покладене на спеціально створені групи інженерних військ (IB) МO. Важкі небезпечні роботи було виконано завдяки наполегливій праці особового складу IB. Варто навести найбільш масштабні роботи 3 ліквідації наслідків катастрофи, які виконували інженерні війська:

- збір та захоронения радіоактивних сполук на території станції на площі 1км²;

- дезактивація місцевості зняттям поверхового шару грунту та його захоронения більш 350 тис.м

- вирубка та захоронения рудого лісу на площі більше ніж 200 га із засипкою грунту;

- підривні та дезактивацій ні роботи на території АЕС тощо. 


\section{Питання психології}

Слід підкреслити, що хімічні війська також виконували низку важливих завдань по ліквідації наслідків на ЧАЕС. Саме ці підрозділи здійснювали:

- повітряну розвідку території AEC i місцевості, взяття проб повітря, грунту, води;

- дозиметричний контроль опромінення i забруднення особового складу, техніки;

- дезактивацію території АЕС, місцевості, населених пунктів, доріг;

- забезпечення військ заходами захисту;

- організацію робіт 3 радіаційного контролю місцевості.

Загалом же всі міністерства і відомства тогочасного Союзу РСР докладали значних зусиль по проведенню визначених урядом держави заходів з ліквідації наслідків аварії на ЧАЕС, надавали підтримку постраждалому населенню, всім тим, хто змушений був залишити так звану тридцяти кілометрову зону відчуження й облаштовувати своє життя у нових місцях поселення.

Відомо, що і в Україні, хоча і $з$ певним запізненням, також була створена система „ліквідаторських структур”. Так, вже 3-го травня розпочала свою роботу Оперативна група політбюро ЦК Компартії України, дії якої узгоджувалися і координувалися з Москвою [8, c.7]. Протоколи засідань i стенограми Оперативної групи зберігаються нині у трьох великих справах, що знаходяться у Центральному державному архіві громадських об'єднань (ЦДАГО) України. Згідно із рішеннями партійних та державних органів влади низка підрозділів та військовослужбовців України безпосередньо брали участь у ліквідації наслідків аварії на Чорнобильській AEC i внесли вагомий вклад у цю важливу справу. Особливе значення в оцінці масштабів катастрофи, розробці прогнозних оцінок, проведені моніторингу радіоактивного забруднення річок, водойм, повітря, грунтів та виробленні конкретних рекомендацій, що не завжди впроваджувалися, мали матеріали установ Академії наук УРСР. До дослідження чорнобильських проблем 3 виїздом на місце залучалося чимало інститутів Академії наук.

Слід відзначити, що у ніч вибуху на ЧАЕС офіційний Київ одразу ж став організатором проведення відповідних заходів. За розпорядженням тодішнього голови Київського облвиконкому I. Плюща у штабі Цивільної Оборони області відразу ж була створена Оперативна група, яка негайно прибула на станцію, щоб детально з'ясувати, що там сталося, i про все доповісти обласному та республіканському керівництву. До іï складу увійшли підполковники В. Нездойминога та I. Мантур - начальники відділів медичного i радіохімічного захисту населення. Очолив групу полковник В. Зінкін [4, с. 43-45]. На станції на випадок кризової ситуації було створено стаціонарний пункт управління діями персоналу.

Треба відзначити, що далеко не всі дії посадових осіб, які опинилися тієї квітневої ночі на $\mathrm{AEC}$, були до кінця чіткими й виваженими, декому з них бракувало професіоналізму. Але і в ту ніч, і в наступні дні та ночі була виконана титанічна робота щодо зменшення радіаційного впливу на людей техногенної катастрофи. За офіційними даними, з четвертого енергоблоку в атмосферу було викинуто близько 6 тон продуктів розпаду, які містили в собі понад 60 кг радіоактивних речовин.

Слід наголосити, що саме військові займалися дезактивацією найбільш радіоактивно забруднених населених пунктів i внесок їх був неоціненним. Генерали О. Корольов, О.Петрохалко, полковники Ю. Колісниченко, Д. Стеблін, майор О. Томленов разом із солдатами свідомо йшли в саме пекло, аби унеможливити розростання катастрофи до зростаючих і непідконтрольних масштабів. Японські роботи зупинялись, не витримавши колосальних навантажень, а люди працювали в таких умовах [4, с. 45].

Під керівництвом союзних структур, зокрема Міністерства енергетики та електрифікації СРСР для виконання комплексу робіт $з$ ліквідації наслідків аварії були задіяні шість військово-будівельних загонів загальною чисельністю 3231 особа. Вони направлялися до району безпосередньої роботи 3 таких військових округів: Уральського округу - 645 чол., Ленінградського - 508 чол., Прибалтійського - 510 чол., Прикарпатського ВО - 527 чол., Одеського - 517 чол., Московського - 524 чол. Показово, що всі вони iз далеких $\mathrm{i}$ власне українських територій прибули до місця дислокації в період 328 


\section{Питання психології}

червня до 4 липня 1986 p. i виконували невідкладні завдання[5, с. 133].

3 перших годин Чорнобильської катастрофи безпосередню участь у з'ясуванні причин аварії та заходах по контррозвідувальному забезпеченню ліквідації iï наслідків узяли понад 1500 співробітників органів держбезпеки УРСР. Тим самим вони здійснили заходи, рівні фронтовим [5, с. 372]. Така увага до ЧАЕС була не випадкова, Чорнобильська AEC - це друга за потужністю станція з ядерної енергетики у Союзі РСР. Вона завжди була об'єктом контррозвідувального забезпечення органів держбезпеки. Ще у передаварійний період оперативними шляхами було здобуто попереджувальну інформацію щодо численних фактів неякісного виконання будівельно-монтажних робіт, постачання бракованого устаткування, порушення принципів технологічної дисципліни та правил радіаційної й пожежної безпеки. Лише у 19831985 pр. сталося 5 аварій і 63 відмови (пробуксовки) основного обладнання, що супроводжувалося значними матеріальними збитками.

Тривожна інформація негайно доповідалася у вищі республіканські партійноурядові інстанції. Однак, належне реагування на неї мало місце далеко не завжди. Коли за матеріалами Прип'ятського міськвідділу КДБ була представлена інформація до ЦК Компартії України, яка свідчила про виток радіаційних речовин з ЧАЕС, вона була кваліфікована як дезінформація, а низка співробітників КДБ отримала стягнення по службі [5, с. 373].

Тож у ніч вибуху - 26 квітня, вже о 2.30 на місце аварії вирушили оперативно-слідчі групи (ОСГ) КДБ УРСР на чолі з генерал-майором Ю. Петровим та заступником начальника 6-го Управління підполковником В. Слободенюком, Управління КДБ по м. Києву та Київській області під керівництвом полковників Г. Свиця та М. Турка. На атомній електростанції працював оперативний склад Прип'ятського міськвідділу УКДБ, який очолив підполковник В. Клочко. У жовтні 1986 р. у Чорнобильській зоні було створено відділ УКДБ, укомплектований офіцерами-добровольцями 3 числа тих, хто мав відповідну інженерну підготовку. Підрозділ, яким керував полковник О. Миргородський, у стислий термін налагодив оперативну роботу зі штабом у селищі Зелений Мис [5, с. 375].

Головним завданням співробітників спецслужби, як і науковців країни, було знайти відповідь на запитання: "Вибух реактора - це технологічна катастрофа чи диверсія?” Одразу ж оперативно-слідчою групою було допитано 48 осіб персоналу АЕС, вилучено й вивчено записи переговорів працівників станції, технічну документацію. Ретельне вивчення різноманітних джерел дозволило згодом категорично відхилити версію про диверсійний акт. Періодом, найскладнішим за радіаційним станом і найвідповідальнішим щодо робіт, які проводилися з ліквідації наслідків аварії, були 1986-1987 рр. (час роботи Урядової комісіі), тоді працювало більше 400 співробітників КДБ СРСР, у тому числі 355 чол. - із КДБ України [5, c. 376].

Неможливо не згадати, що у винятково складній обстановці в перші години після аварії співробітники Управління урядового зв’язку та восьмого відділу КДБ розгорнули рухомі й стаціонарні вузли спеціального та шифрованого зв’язку за паролем „Б” (Блискавка) [5, с. 378]. Вдень 26 квітня перший екіпаж зв'язку установив антену радіорухомої системи зв'язку „Роса" на даху міськкому. Під час монтажу йшов рудий дощ, суміш води та радіоактивного пилу із зруйнованого реактора. Антена була встановлена вчасно, що дало можливість організувати стійкий радіозв'язок 3 рухомими об'єктами в зоні. Незважаючи на відсутність засобів захисту, екіпаж виконав поставлене завдання.

Також необхідно відзначити, що в комплексі оперативно-службових заходів, пов'язаних 3 аварією на ЧАЕС, брали участь практично всі основні підрозділи КДБ України. В особливому режимі працювала „перша лінія” - зовнішня розвідка. Перед нею було поставлено конкретне завдання: оперативно здобути за кордоном усе, що сприятиме подоланню жахливих наслідків Чорнобильського лиха.

Співробітники Третього Управління (військова контррозвідка) КДБ УРСР забезпечували взаємодію оперативної слідчої групи (ОСГ) зі штабами МВС та Цивільної оборони, здійснювали спільні 


\section{Питання психології}

контррозвідувальні заходи 3 особливими відділами КДБ у військових частинах.

Вже 3 перших днів аварії необхідно було розробити рекомендації стосовно правил поведінки людини в умовах тривалого надходження в організм радіонуклідів, здійснити відбір співробітників для направлення в зону ЧАЕС, організувати їх систематичне обстеження i проведення профілактичних та лікувальних заходів зі своєчасною відправкою хворих 3 гострими променевими ушкодженнями до спеціалізованих медичних установ країни. Крім того, необхідно було організувати дозиметричний, контроль у зоні ЧАЕС і на об'єктах КДБ, підготувати персонал МВС КДБ УРСР 3 питань діагностики, лікування, профілактики променевих уражень. Основне завдання медиків було чітким і зрозумілим зберегти життя і здоров'я співробітників, які 3 перших годин після аварії знаходилися в центрі подій. Проте говорити нині про суттєве поліпшення радіоекологічного стану ураженої території, про іiі повну безпеку для людей i навколишнього середовища завчасно. Тож нині головною метою діяльності в зоні відчуження залишається ліквідація наслідків Чорнобильської катастрофи та мінімізація екологічної небезпеки для населення України 3 наступним переведенням iï в екологічно безпечний стан на всіх етапах утримання $[6$, с. 245]. Певно, що суверенна Україна спроможна справитися з цим викликами і вивести належні уроки із цієї вкрай небезпечної аварії.
Висновки. Таким чином, до ліквідації аварії на ЧАЕС та іï наслідків була залучена велика кількість людей різного фаху та соціального стану: військові, пожежники, шахтарі, науковці, водіï, медики та багато інших. Але потрібно віддати належне військовослужбовцям, які незважаючи на небезпеку, що загрожувала їх життю, з честю виконували поставлені завдання. Унікальність і величезна складність та небезпека завдань вимагала особливої організаційної структури управління військами і всіма засобами. Тому були створені Оперативні групи управління в Генеральному штабі, в Головному штабі ВПС, управліннях начальників хімічних і інженерних військ, Цивільної оборони, в головних і центральних управліннях Міністерства оборони. Тисячі радянських людей безстрашно вступили у боротьбу з Чорнобильської бідою, проявивши мужність та героїзм, талановиті організатори непередбаченої роботи, здійснили подвиг.

Своїм відлунням Чорнобильська катастрофа спонукає нас до пильності. Вона знову і знову примушує замислитися над тим, що науково-технічний прогрес не тільки дає сучасній людині засоби, щоб досягти намічених цілей на шляху цивілізованого поступу, а й вимагає i дозволяє знаходити запобіжники, котрі дають гарантії безпеки. А це прямо пов'язано 3 формуванням i розвитком світоглядних, моральних засад, які об’єднують людей.

\section{Список використаних джерел}

1. Возняк В.Я., Коваленко А.П., Троицкий С.Н. Чернобыль: события и уроки. Вопросы и ответы. - М.: Политиздат, 1989. - 245 с.

2. Нецька Л. Зворотній бік Чорнобильської катастрофи // Військо України,- 2003.-№ 3-4.- С.5-7.

3. Бар'яхтар В.Г. Чорнобильська катастрофа. - К.,1996. - 672 с.

4. Зятьев С. Біля кратера атомного вулкана // Надзвичайна ситуація,- 2002. -№ 4,- С. $43-45$.

5. 3 архівів ВУЧК, КПУ, НКВД, КГБ. - 2001. - № 1. Спецвипуск. - 395 с.

6. Барановська Н.П. Спорудження укриття над зруйнованим 4-м енергоблоком ЧАЕС. // 36. науковопопулярних статей. Українське суспільство. Друга половина XX століття. Історія та сучасність. - К.: Інституг історії, 2002.- 259 c.

7. Дьяченко А.А. Опыт ликвидации последствий Чернобыльской катастрофы. - М. 1998. - 385 с.

8. Чорнобильська трагедія. Документи і матеріали. - К.: Наукова думка. - 1996. - 784 с.

\section{References}

1. Voznyak V.Ya.. Kovalenko A.P.. Troitskiy S.N. Chernobyl: sobytiya i uroki. Voprosy i otvety. - M.: Politizdat. 1989. - 245 s (in Russian).

2. Netska L. Zvorotnii bik Chornobylskoi katastrofy // Viisko Ukrainy,- 2003.-№ 3-4.- S.5-7 (in Ukraine).

3. Bariakhtar V.H. Chornobylska katastrofa. - K.,1996. - 672 s (in Ukraine). 


\section{Питання психології}

4. Ziatev S. Bilia kratera atomnoho vulkana // Nadzvychaina sytuatsiia,- 2002. -№ 4,- S. $43-45$ (in Ukraine).

5.3 arkhiviv VUChK, KPU, NKVD, KHB. - 2001. - № 1. Spetsvypusk. - 395 s (in Ukraine).

6. Baranovska N.P. Sporudzhennia ukryttia nad zruinovanym 4-m enerhoblokom ChAES. // 36. naukovopopuliarnykh statei. Ukrainske suspilstvo. Druha polovyna XX stolittia. Istoriia ta suchasnist. - K.: Instytut istorii, 2002.$259 \mathrm{~s}$ (in Ukraine).

7. Diachenko A.A. Opyt likvidatsii posledstviy Chernobylskoy katastrofy. - M. 1998. - 385 s (in Russian).

8. Chornobylska trahediia. Dokumenty i materialy. - K.: Naukova dumka. - 1996.- $784 \mathrm{~s}$ (in Ukraine).

\section{Резюме \\ Солошенко Н. В. старишй научный сотрудник НИЛ \\ кафедры общественных наук НУОУ им Ивана Черняховского \\ ЛИКВИДАЦИЯ ПОСЛЕДСТВИЙ ЧЕРНОБЫЛЬСКОЙ КАТАСТРОФЫ 1986 р. И ВКЛАД УКРАИНСКИХ ВОЕННОСЛУЖАЩИХ}

В статье анализируются проблемы, которые возникли и были решены при участии военных частей бывшего Советского Союза и УССР в первые дни и месяиь после Чернобыльской катастрофы 1986 р. в значительной степени благодаря созданию особенной организаиионной структуры управления войсками. Освещается героизм и мужество военнослужсащих, проявленные при ликвидации последствий самой маситабной аварии в истории атомной энергетики.

Ключевые слова: Чернобыльская АЭС; катастрофа; военнослужашие; химические и инженерные войска; отселение.

\section{Summary \\ Soloshenko $N$. V. senior research worker of scientific research laboratory of Social Sciences Department of the National Defence University of Ukraine named after Ivan Cherniakhovskyi https: orcid. org/0000-0002-6537-1107 \\ ELIMINATION OF THE CONSEQUENCES OF THE CHERNOBYL DISASTER OF 1986 AND THE CONTRIBUTION OF THE UKRAINIAN MILITARY}

The article analyzes the problems that arose and were solved with the participation of military units of the former Soviet Union and the Ukrainian SSR in the first days and months after the 1986 Chernobyl disaster, largely due to the creation of a special organizational structure for troop management. The heroism and courage of the servicemen demonstrated during the liquidation of the consequences of the largest accident in nuclear energy are highlighted.

Problem Statement. An accident that escalated into a large-scale catastrophe of humanitarian, environmental and economic nature. The aftermath of the Chernobyl disaster has provided Ukrainian military with invaluable experience that needs to be estimated.

The Purpose lies in a comprehensive understanding of the place and significance of the Chornobyl catastrophe in the history of Ukraine and the participation of Ukrainian servicemen in the liquidation of the catastrophe.

Research Methods. The following methods were used in the research process: comparative-historical and descriptive methods, content analysis and synthesis.

Originality consists in the introduction into scientific circulation of new sources, highlighting the heroism and courage of the servicemen, shown in the elimination of the consequences of the greatest accident in nuclear energy.

Conclusion. The echo of the Chornobyl catastrophe urges us to be vigilant. It makes us rethink that scientific and technological progress not only gives modern mankind the means to achieve the intended goals on the path of civilized progress, but also requires and allows to find fuses that provide security guarantees.And this is directly related to the worldviews formation and development, moral principles that unite people. We and the next generations must not forget the Chernobyl tragedy, which took place in a picturesque corner of Ukraine and caused many disasters for our people. This catastrophe is a warning both Ukraine and the entire international community. Mankind must draw conclusions from this experience and prevent similar catastrophes in the future.

Key words: Chernobyl nuclear power plant; catastrophe; servicemen; chemical and engineering troops; resettlement.

Recelved/Поступила: 24.12.20. 